\title{
Synthesis, Structure, Tautomerism and Reactivity of Methanetrisamidines
}

\author{
Benjamin Gutschank, Stephan Schulz, * Michael Marcinkowski, Georg Jansen, Heinz Bandmann, \\ Dieter Bläser, Christoph Wölper
}

$\mathrm{N}, \mathrm{N}$-chelating monoanionic amidinate ligands have been studied in detail within the last decades due to the easy tunability of their steric and electronic properties, ${ }^{[1]}$ which allows the synthesis of tailor made metal complexes for technical applications in catalysis and materials sciences. ${ }^{[2]}$ Surprisingly, multifunctional ligands containing two or more amidine moieties, in the following referred to as polyamidines, have been only scarcely investigated. They are of potential interest for the synthesis of (hetero)multimetallic complexes, which may show improved catalytic properties. Moreover, neutral aromatic tetraamidines were investigated in cancer research due to their anti-proteinase activity. ${ }^{[3]}$ Unfortunately, only very few polyamidines, almost exclusively containing a central phenyl-spacer, have been synthesized and multidentate polyamidines, in which the amidine moieties are bound to a single atom, are limited to two $\mathrm{Me}_{2} \mathrm{Si}$ - and $\mathrm{CH}_{2}$-bridged derivatives. ${ }^{[4,5]}$ In contrast, isoelectronic tetranitromethane $\mathrm{C}\left(\mathrm{NO}_{2}\right)_{4}$ and tetramethylmethanetetracarboxylate $\mathrm{C}(\mathrm{COOMe})_{4}$ are well known. ${ }^{[6]}$

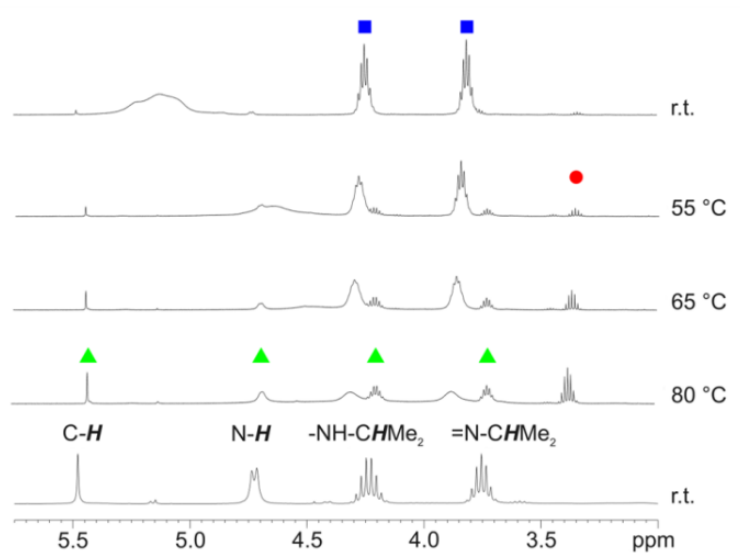

Figure 1. Temperature-dependent ${ }^{1} \mathrm{H}$ NMR monitoring showing the hydrolysis of $1 \mathbf{a}$ with water in $\mathrm{C}_{6} \mathrm{D}_{6}\left(\mathbf{1 a} \mathbf{a}, \mathbf{2 a} \Delta, \mathrm{C}(\mathrm{Ni}-\mathrm{Pr})_{2} \bullet\right)$.

We recently reported on the synthesis of tetraamidinatomethane complexes $\left\{\mathrm{C}\left[\mathrm{C}(\mathrm{NR})_{2} \mathrm{ZnMe}\right] 4\right\}(\mathrm{R}=i$-Pr 1a; Ph 1b, Et 1c, Cy 1d) by reactions of $\mathrm{ZnMe}_{2}$ with carbodiimides at elevated temperatures and their reactivity. ${ }^{[7,8]}$ We now became interested in the neutral multidentate ligands, which were expected to be formed by kinetically-controlled hydrolysis of the zinc complexes. However,

[*] B. Gutschank, Prof. S. Schulz*, M. Marcinkowski, Prof. G. Jansen, Dipl. Ing. H. Bandmann, D. Bläser, Dr. C. Wölper Faculty of Chemistry, University of Duisburg-Essen Universitätsstr. 5-7, S07 S03 C30, D-45117 Essen Fax: (+) 201-183 3830

E-mail: stephan.schulz@uni-due.de

$[* *]$ S. Schulz gratefully acknowledges financial support by the University of Duisburg-Essen.

Supporting information for this article is available on the WWW under http://www.angewandte.org or from the author. temperature dependent in situ ${ }^{1} \mathrm{H}-\mathrm{NMR}$ monitoring (Fig. 1) of the reaction of 1a with water in $\mathrm{C}_{6} \mathrm{D}_{6}$ showed a different reaction pathway. 1a is almost stable against hydrolysis at ambient temperature, whereas heating of the solution to $55^{\circ} \mathrm{C}$ exclusively yielded $(i-\operatorname{PrN})_{2} \mathrm{C}$ and methanetrisamidine 2a, respectively. Even though $\mathrm{C}[\mathrm{C}(\mathrm{NR}) \mathrm{N}(\mathrm{R}) \mathrm{H}]_{4}$ was not detected by NMR spectroscopy, its formation as reaction intermediate cannot be excluded. Comparable decomposition reactions were found for isoelectronic $\mathrm{C}\left(\mathrm{NO}_{2}\right)_{4}$ and $\mathrm{C}(\mathrm{COOMe})_{4}$, which react under basic conditions with

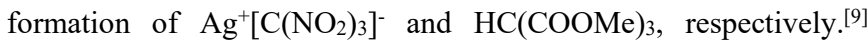
However, an analogous carbodiimide elimination reaction was only observed for metal amidinates $(\mathrm{Cu}, \mathrm{Al})$ upon thermal treatment at temperatures higher than $200{ }^{\circ} \mathrm{C} \cdot{ }^{[10]}$ Considering the significantly lower reaction temperatures in our experiments, the decomposition of 1a is expected to proceed by a different reaction pathway, most likely by an intramolecular H-migration (SI).

2a was purified by sublimation at $80^{\circ} \mathrm{C}$. The ${ }^{1} \mathrm{H}$ NMR spectrum shows a singlet $\left(5.37 \mathrm{ppm}\right.$, toluene- $\left.\mathrm{d}_{8}\right)$ of the central $\mathrm{CH}$ group, whereas the $\mathrm{NH}$ resonance $(4.63 \mathrm{ppm})$ occurred as a doublet due to ${ }^{3} \mathrm{~J}_{\mathrm{HH}}$ coupling to $\mathrm{CH}_{i \text {-Pr. }}$. Dynamic ${ }^{1} \mathrm{H}-\mathrm{NMR}$ and DEPT experiments between -40 and $+100{ }^{\circ} \mathrm{C}$ showed no $\mathrm{CH}-\mathrm{NH}$ tautomerization reaction of the central $\mathrm{C}-\mathrm{H}$ group. In contrast, hydrolysis of $\mathbf{1 b}$ yielded both tautomers $\mathrm{C}[\mathrm{C}(\mathrm{NPh}) \mathrm{N}(\mathrm{Ph}) \mathrm{H}]_{2}\left[\mathrm{C}(\mathrm{HNPh})_{2}\right]$ 2b and $\mathrm{HC}[\mathrm{C}(\mathrm{NHPh}) \mathrm{NPh}]_{3}$ 2c. 2b and $\mathbf{2 c}$ are the first structurally characterized $\mathrm{CH}-\mathrm{NH}$ tautomers of an acyclic amidine. Even though $\mathrm{N}, \mathrm{N}^{\prime}$-tautomerism in amidines was investigated in detail, ${ }^{[11]}$ the existence of a $\mathrm{CH}-\mathrm{NH}$ tautomeric equilibrium was proven only indirectly due to the short-lived ene-1,1-diamine species, which could not be isolated, to date. ${ }^{[12]}$ In contrast, a cyclic ene-1,1diamine has been previously characterized by NMR spectroscopy. ${ }^{[13]}$ The postulated N-H tautomer of acetamidine plays a crucial role in the Diels-Alder reaction with tetrazine derivatives forming aminopyridazines. ${ }^{[14]}$ In addition, the cyclic ketene-N,N acetal is assumed as a key intermediate in the synthesis of tetraazafulvalenes by oxidative coupling. ${ }^{[15]}$

Colorless crystals were obtained by slow evaporation of the solvent from a solution in cyclohexane $/ \mathrm{CH}_{2} \mathrm{Cl}_{2}(\mathbf{2 b})$ and from a solution in $\mathrm{CH}_{3} \mathrm{CN}$ upon storage at $-10{ }^{\circ} \mathrm{C}(\mathbf{2 c}) \cdot{ }^{[16]}$ The central carbon atom $\mathrm{C} 1$ in $\mathbf{2 b}$, which binds to three carbon atoms in a trigonal-planar arrangement (r.m.s. deviation of the four $\mathrm{C}$ atoms from the best plane is $0.0044 \AA$ ), can be considered as $\mathrm{sp}^{2}$ hybridized. $\mathrm{C} 1-\mathrm{C} 2$ and $\mathrm{C} 1-\mathrm{C} 3$ are slightly shorter than typical single bonds $(1.54 \AA)$ and $\mathrm{C} 1-\mathrm{C} 4$ is longer than a common double bond $(1.34 \AA)$, indicating a delocalization of $\pi$-electrons. The same is true for both $\mathrm{C}-\mathrm{N}$ bonds emerging from $\mathrm{C} 4$, which are shorter than the expected value for a $\mathrm{C}\left(\mathrm{sp}^{2}\right)-\mathrm{N}\left(\mathrm{sp}^{3}\right)$ single bond (1.43 $\AA$ ). In contrast, one $\mathrm{C}-\mathrm{N}$ bond at $\mathrm{C} 2$ and $\mathrm{C} 3$ shows the typical value of a $\mathrm{C}-\mathrm{N}$ double bond $(1.29 \AA)$, while the other agree well with the mean $\mathrm{C}-\mathrm{N}$ single bond length as found for $\mathrm{RNH}-\mathrm{CR}=\mathrm{NR}$ moieties in the CSD (1.372(28) $\AA$ ). The structural parameters of the molecule agree well with the hydrogen atom positions found in the difference Fourier synthesis. The conformation of the molecule is supported by two intramolecular hydrogen bonds. 
The central carbon atom $(\mathrm{C} 1)$ in $\mathbf{2 c}$ binds to three amidine groups and one hydrogen position was found next to it in the difference Fourier synthesis, which coincides with the other structural parameters. The $\mathrm{C}-\mathrm{C}$ bond lengths are in the typical range of C-C-single bonds and the $\mathrm{C}-\mathrm{C} 1-\mathrm{C}$ bond angles are about $113^{\circ} . \mathrm{C} 1$ deviates by $0.4180(12) \AA$ from the $\mathrm{C} 2 / \mathrm{C} 3 / \mathrm{C} 4$-plane, indicating a sp ${ }^{3}$ hybridization. The enlarged angles compared to the tetrahedron angle can be explained by the steric demand of the residual groups. The C-N bond lengths show typical values of double and single bonds (vide supra).

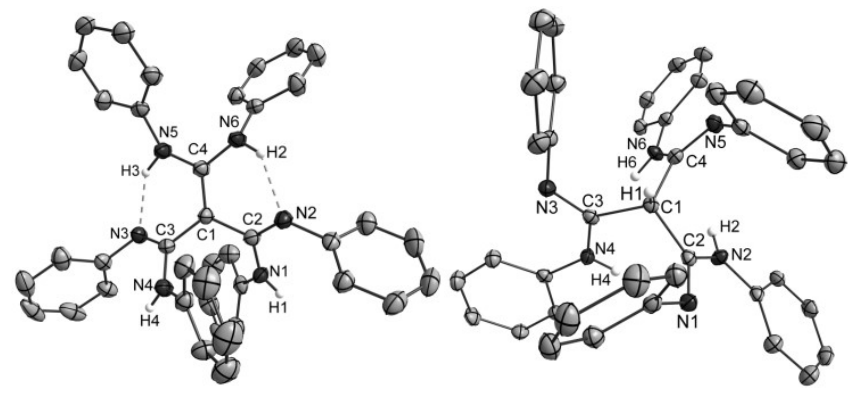

Figure 2. Molecular structure of $\mathbf{2 b}$ (left) and of $\mathbf{2 c}$ (right); thermal thermal ellipsoids at $50 \%$ probability levels, hydrogen atoms at arbitrary radii, phenyl hydrogen atoms omitted for clarity. Bond lengths $[\AA]$ and angles [ $\left.{ }^{\circ}\right]$ : 2b: $\mathrm{C}(1)-\mathrm{C}(2) 1.486(2), \mathrm{C}(1)-\mathrm{C}(3) 1.476(2)$, $\mathrm{C}(1)-\mathrm{C}(4)$ 1.391(2), N(1)-C(2) 1.374(2), N(2)-C(2) 1.294(2), N(5)-C(4) 1.372(2), N(6)-C(4) 1.373(2), C(4)-C(1)-C(3) 121.38(13), C(4)-C(1)$\mathrm{C}(2) 120.64(14), \mathrm{C}(3)-\mathrm{C}(1)-\mathrm{C}(2) 117.97(14), \mathrm{N}(2)-\mathrm{C}(2)-\mathrm{N}(1)$

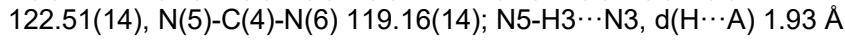
$<(\mathrm{DH} \cdots \mathrm{A})$ 138.6, N6-H2 $\cdots \mathrm{N} 2, \mathrm{~d}(\mathrm{H} \cdots \mathrm{A}) 1.97 \AA,<(\mathrm{DH} \cdots \mathrm{A})$ 137.0; 2c: $\mathrm{C}(1)-\mathrm{C}(2)$ 1.5356(14), C(1)-C(3) 1.5345(14), C(1)-C(4) 1.5341(15), $\mathrm{N}(1)-\mathrm{C}(2) 1.2819(14), \mathrm{N}(2)-\mathrm{C}(2) 1.3644(14), \mathrm{C}(4)-\mathrm{C}(1)-\mathrm{C}(3)$ 113.04(8), $\mathrm{C}(4)-\mathrm{C}(1)-\mathrm{C}(2)$ 112.37(9), C(3)-C(1)-C(2) 113.21(9), N(1)-C(2)-N(2) 121.88(10).

To elucidate the solvent dependency of the equilibrium between 2b and 2c, temperature-dependent NMR experiments were performed in $\mathrm{C}_{6} \mathrm{D}_{6}$ and $\mathrm{CD}_{3} \mathrm{CN}$. The major form in non-polar $\mathrm{C}_{6} \mathrm{D}_{6}$ is $\mathbf{2 b}$ (more than $85 \%$ ) over the whole temperature range (25 $\left.75{ }^{\circ} \mathrm{C}\right) .{ }^{13} \mathrm{C}$ and DEPT90 spectra only showed four broadened phenyl resonances due to a fast intramolecular proton exchange reaction between the amino and imino groups. Consequently, the C$\mathrm{C}$ double bond is delocalized within the planar $\mathrm{C}_{4}$-moiety, which explains the enhanced stability of $\mathbf{2} \mathbf{b}$. Characteristic resonances of the ene-1,1-diamidine carbon atom (84.96 ppm), the amidino backbone carbon atoms (153.74 ppm) and the ene-diamine carbon atom $(143.53 \mathrm{ppm})$ could be clearly assigned, whereas NMR spectra of $\mathbf{2 b}$ in polar $\mathrm{CD}_{3} \mathrm{CN}$ show an increasing amount of $\mathbf{2 c}$ upon heating from 25 to $75{ }^{\circ} \mathrm{C}$. High temperatures are required due to the poor solubility of $\mathbf{2 c}$. The formation of $\mathbf{2 c}$ rather points to a solvent (e.g. polarity) than to a temperature dependency, hence allowing to control the equilibrium to some extent via solvent polarity. ${ }^{[17]}$

Dispersion-corrected density functional theory (DFT $+\mathrm{D} 3)$ calculations were performed to evaluate the relative stability of the $\mathrm{N}-\mathrm{H}$ (2b) and C-H (2c) tautomers in more detail.. ${ }^{[18]}$ Upon convergence of the geometry optimizations, 2b displays $\mathrm{C}_{2}$ symmetry, while $2 \mathrm{c}$ is $\mathrm{C}_{3}$ symmetric. Phenyl groups surround the methine group in $2 \mathbf{c}$ with $\mathrm{H}_{\text {ortho }} \cdots \mathrm{C}_{\text {meta }}$ distances of $2.87 \AA$ (XRD $2.98,3.02,3.13 \AA$ ), proving the stabilizing effect of the three $\mathrm{CH}-\pi$ contacts. The calculated $\mathrm{C} 1-\mathrm{C} 2$ distance $(1.545 \AA)$ and $\mathrm{C} 2-\mathrm{C} 1-\mathrm{C} 3$ angle $\left(113.2^{\circ}\right)$ are in excellent agreement with the crystal structure. The remaining three phenyl groups do not show substantial $\mathrm{CH}-\pi$ or $\pi-\pi$ stabilizations, but one of their $\mathrm{H}_{\text {ortho }}$ atoms involved in a nearly planar six-membered H-C-C-N-C-N ring is only $2.28 \AA$ away from the adjacent $\mathrm{N}$ atom. A further stabilization of this geometry may be attributed to the three $\mathrm{NH} \cdots \mathrm{N}$ contacts $(2.55 \AA)$ between the different $\mathrm{C}(\mathrm{NHPh})(\mathrm{NPh})$ groups. In $\mathbf{2 b}$ only two $\mathrm{CH}-\pi$ contacts were found, with a $\mathrm{H}_{\text {ortho }} \cdots \mathrm{C}_{\text {para }}$ distance of $2.87 \AA$ (XRD 2.87, 2.90 $\AA)$. On the other hand, one $\pi-\pi$ contact in a typical parallel-displaced arrangement of two phenyl rings of adjacent $\mathrm{C}(\mathrm{NHPh})(\mathrm{NPh})$ moieties and two short $\mathrm{NH} \cdots \mathrm{N}$ bonds of $1.80 \AA$ (XRD 1.93, $1.97 \AA$ ), which help to stabilize $2 \mathbf{b}$ over $2 \mathbf{c}$ by $10.6 \mathrm{~kJ} / \mathrm{mol}$ according to $\mathrm{DFT}+\mathrm{D} 3$, were found. The calculated C1-C2 distance $(1.475 \AA)$ agrees very well with experimental values (C1-C2 1.486(2), C1-C3 $1.476(2) \AA$ ), while the $\mathrm{C} 1-\mathrm{C} 4$ distance of $1.420 \AA$ points to a slightly higher single-bond character in the calculated structure compared to the crystal structure (1.391(2) $\AA$ ). The DFT+D3 energy difference agrees well with the value of $12.3 \mathrm{~kJ} / \mathrm{mol}$ as found in $a b$ initio calculations for the DFT $+\mathrm{D} 3$ geometries using valence-only second-order Møller-Plesset perturbation theory (MP2). ${ }^{[19]}$ In conjunction with an increase of the dipole moment from 0.97 Debye (2b) to 2.42 Debye (2c) as obtained from DFT + D3, this energy difference is small enough to explain why $\mathbf{2 b}$ is preferred but not exclusively formed in non-polar solvents whereas $\mathbf{2 c}$ dominates in polar solvents (vide supra).

Replacement of the phenyl groups by $\mathrm{H}$ atoms followed by geometry optimization and vibration frequency calculation at the $\mathrm{DFT}+\mathrm{D} 3$ level again shows the $\mathrm{C}_{2}$-symmetrical $\mathrm{N}-\mathrm{H}$ and the $\mathrm{C}_{3}-$ symmetrical $\mathrm{C}-\mathrm{H}$ tautomeric forms as true minima on the potential energy surface. ${ }^{[20]}$ The $\mathrm{N}-\mathrm{H}$ tautomer is preferred by $23.8 \mathrm{~kJ} / \mathrm{mol}$, in good agreement with the MP2 energy difference of $22.1 \mathrm{~kJ} / \mathrm{mol}$ obtained for the DFT $+\mathrm{D} 3$ geometries, which changes only slightly to $23.1 \mathrm{~kJ} / \mathrm{mol}$ upon re-optimization of the structures at the MP2 level of theory. The $\pi-\pi$ contact between adjacent $\mathrm{C}(\mathrm{NHPh})(\mathrm{NPh})$ groups observed in $\mathbf{2 b}$ is now replaced with two $\mathrm{NH} \cdots \mathrm{N}$ contacts with an N-H distance of $2.50 \AA$, while $\mathrm{CH}-\pi$ contacts obviously no longer exist, which rationalizes the increased energy difference between the tautomeric forms. Upon releasing the $\mathrm{C}_{3}$ symmetry constraint a second, deeper minimum with $\mathrm{C}_{1}$ symmetry for the $\mathrm{C}-\mathrm{H}$ tautomer was found (see SI). This structure is $20.9 \mathrm{~kJ} / \mathrm{mol}$ higher in energy than the N-H tautomer at the DFT+D3 level of theory, while only $16.1 \mathrm{~kJ} / \mathrm{mol}$ were obtained with MP2 $(17.1 \mathrm{~kJ} / \mathrm{mol}$ after MP2 re-optimization of both structures).

To determine the energy difference between the (unobserved) $\mathrm{N}-\mathrm{H}$ and $\mathrm{C}-\mathrm{H}$ (2a) tautomers of the $i$-Pr substituted trisamidine, a molecular mechanics force field conformer scan was carried out for both tautomers. The energetically lowest $12 \mathrm{~N}-\mathrm{H}$ tautomeric and 15 $\mathrm{C}-\mathrm{H}$ tautomeric structures were then re-optimized at the DFT $+\mathrm{D} 3$ level with a small basis set of split-valence quality, before finally reoptimizing the resulting lowest two conformers for each tautomer at the DFT $+\mathrm{D} 3$ level with a triple-zeta basis set. A $\mathrm{C}_{1}$-symmetrical conformer of 2a was found to be $1.9 \mathrm{~kJ} / \mathrm{mol}$ lower in energy than any conformer of the N-H tautomer, the lowest of which was found to display $\mathrm{C}_{2}$ symmetry. The next conformer of $\mathbf{2 a}\left(\mathrm{C}_{1}\right.$ symmetry) was found at $2.0 \mathrm{~kJ} / \mathrm{mol}$, while the energy of next conformer $\left(\mathrm{C}_{1}\right)$ of the $\mathrm{N}-\mathrm{H}$ tautomer is $5.6 \mathrm{~kJ} / \mathrm{mol}$ higher than the lowest conformer of 2a. The energy difference between the lowest conformers of both tautomers increases to $3.3 \mathrm{~kJ} / \mathrm{mol}$ on the MP2 level of theory (without re-optimization of the DFT+D3 structures), which is too small to explain why only 2a has been experimentally observed. However, the dipole moment of $\mathbf{2 a}$ is 2.42 Debye (DFT+D3), while that of the two conformers of the N-H tautomer is only 1.02 and 1.07 Debye, respectively. Interactions with neighboring dipole 
molecules or a polarizable environment may have a stabilizing effect, subsequently favoring the $\mathrm{C}-\mathrm{H}$ tautomeric form $\mathbf{2 a}$.

The imino moieties of the methanetrisamidines are proton acceptors as was shown by reaction of $\mathbf{2} \mathbf{b}$ with two equivalents of acetic acid, yielding $\left[\mathrm{C}\left(\mathrm{C}(\mathrm{HNPh})_{2}\right)_{3}\right]^{2+}\left\{\left[\mathrm{CH}_{3} \mathrm{COO}\right]^{-}\right\}_{2} \quad \mathbf{3}$ (SI). Crystals of $\mathbf{3}$, which crystallizes in the triclinic space group $P$, were obtained from a solution in $\mathrm{Et}_{2} \mathrm{O}$ at $-30{ }^{\circ} \mathrm{C}$. The most notable structural difference between $\mathbf{2 b}$ and the methanetrisamidinium dication in $\mathbf{3}$ is reflected by the almost equal $\mathrm{C}-\mathrm{C}$ bond lengths within the trigonal planar $\mathrm{C}_{4}$-moiety (C1-C2 1.417(2) $\AA$, C1-C3

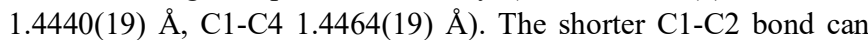
be explained by the orientation of the N-C-N unit relative to the central $\mathrm{C}_{4}$ unit. The $\mathrm{N} 1 / \mathrm{C} 2 / \mathrm{N} 2$ plane is almost coplanar to the $\mathrm{C} 1 / \mathrm{C} 2 / \mathrm{C} 3 / \mathrm{C} 4$ plane $\left(26.51(15)^{\circ}\right)$, which allows a more effective $\pi$ electron delocalization compared to the other two amidinate groups $\left(40.27(13)^{\circ}, 43.38(10)^{\circ}\right)$ and explains the slightly elongated $\mathrm{C} 2-\mathrm{N}$ bonds and the slightly shorter $\mathrm{C} 1-\mathrm{C} 2$ bond.

In addition, ampholytic 2a-c are powerful reagents for the synthesis of multinuclear organometallic complexes due to the presence of acidic $\mathrm{N}-\mathrm{H}$ groups. Reactions of $\mathbf{2 a}$ with $\mathrm{AlMe}_{3}$ and $i$ $\mathrm{Bu}_{2} \mathrm{AlH}$ occurred with elimination of methane or $\mathrm{H}_{2}$, respectively, and subsequent formation of $\mathrm{HC}\left[\mathrm{C}(\mathrm{N} i-\mathrm{Pr})_{2} \mathrm{AlR}_{2}\right]_{3}(\mathrm{R}=\mathrm{Me} \mathbf{4 a}, i-\mathrm{Bu}$ 4b) in quantitative yields. Threefold deprotonation was proven by disappearance of the $\mathrm{NH}$ resonances in the ${ }^{1} \mathrm{H}$ NMR spectra $\left(\mathrm{C}_{6} \mathrm{D}_{6}\right)$, whereas the characteristic $\mathrm{CH}$ group was preserved. Crystals of $\mathbf{4 a}$ and $\mathbf{4 b}$ of low quality were obtained from different solvents, from which the connectivity within the molecules was proven. The models suggest a $\mathrm{sp}^{3}$ hybridization of the central carbon atom and a chelating coordination of the amidinate groups to the $\mathrm{AlR}_{2}$ units.

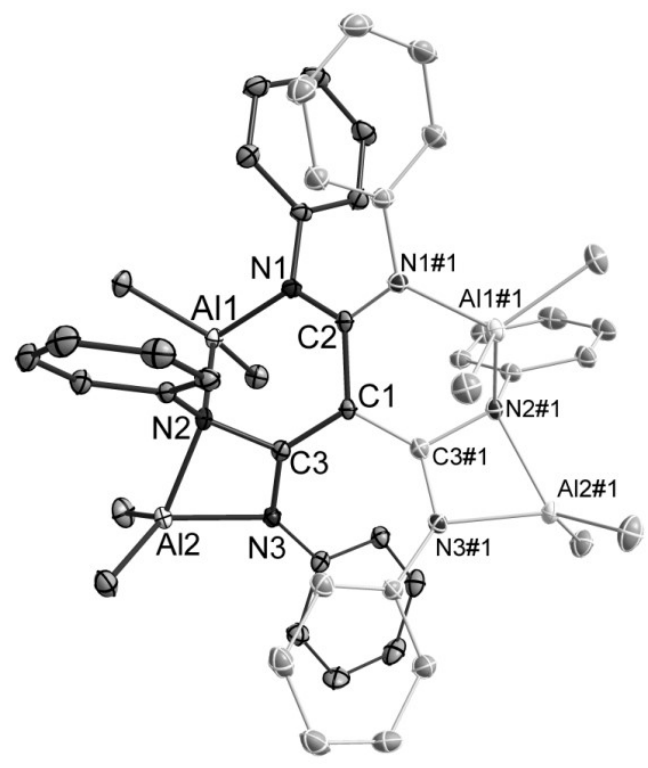

Figure 3. Molecular structure of 4c (thermal ellipsoids at 50\% probability levels, hydrogen atoms omitted for clarity, asymmetric unit shown in dark bonds, $\mathrm{C} 1$ and $\mathrm{C} 2$ located on a two-fold axis). Bond lengths $[\AA]$ and angles $\left[^{\circ}\right], \# 1-x+1, y,-z+1 / 2: C(1)-C(2) 1.506(2), C(1)-$ $\mathrm{C}(3)$ 1.4191(15), N(2)-C(3) 1.4470(15), N(3)-C(3) 1.3257(16), N(1)$\mathrm{C}(2)$ 1.3404(13), $\mathrm{Al}(1)-\mathrm{N}(1)$ 1.9199(11), $\mathrm{Al}(1)-\mathrm{N}(2)$ 1.9984(11), $\mathrm{Al}(2)-$ $\mathrm{N}(3)$ 1.9268(11), Al(2)-N(2) 1.9967(11), C(3)\#1-C(1)-C(3) 120.55(16), $\mathrm{C}(3) \# 1-\mathrm{C}(1)-\mathrm{C}(2)$ 119.73(8), C(3)-C(1)-C(2) 119.73(8), N(1)-C(2)$\mathrm{N}(1) \# 1$ 125.02(16), N(1)-C(2)-C(1) 117.49(8), N(3)-C(3)-C(1) 132.19(12), N(3)-C(3)-N(2) 105.46(10), C(1)-C(3)-N(2) 122.29(11), $\mathrm{C}(2)-\mathrm{N}(1)-\mathrm{C}(4)$ 120.32(11), C(2)-N(1)-Al(1) 125.64(9), C(4)-N(1)-Al(1) 113.22(8), C(3)-N(2)-C(10) 120.94(10), C(3)-N(2)-Al(2) 89.32(7), $\mathrm{C}(10)-\mathrm{N}(2)-\mathrm{Al}(2)$ 112.40(8), C(3)-N(2)-Al(1) 101.14(7), C(10)-N(2)$\mathrm{Al}(1)$ 112.80(8), $\mathrm{Al}(2)-\mathrm{N}(2)-\mathrm{Al}(1)$ 118.29(5), C(3)-N(3)-C(16)
132.96(11), C(3)-N(3)-AI(2) 96.09(8), C(16)-N(3)-AI(2) 129.65(8), $\mathrm{N}(1)-\mathrm{Al}(1)-\mathrm{N}(2)$ 90.67(5), N(3)-Al(2)-N(2) 68.46(4).

In contrast, the reaction of $\mathbf{2 b}$ with a fourfold amount of $\mathrm{AlMe}_{3}$ gave $\mathrm{C}\left[\mathrm{C}(\mathrm{NPh})_{2} \mathrm{AlMe}_{2}\right]_{2}\left[\mathrm{C}\left(\mathrm{N}(\mathrm{Ph}) \mathrm{AlMe}_{2}\right)_{2}\right] \mathbf{4} \mathbf{c}$ in quantitative yield. Yellow crystals of $4 \mathbf{c}$ were obtained from a solution in toluene at $30{ }^{\circ} \mathrm{C} .4 \mathbf{c}$ crystallizes in the monoclinic space group $C 2 / \mathrm{c}$ with $\mathrm{C} 1$ and $\mathrm{C} 2$ on a two-fold axis. One amidinate group (N1-C1-N1\#1) adopts a bridging position, while two serve as chelating units. The $\mathrm{C}$ atoms of the amidinate groups bind to trigonal-planar coordinated $\mathrm{C} 1$ with two short and one long $\mathrm{C}-\mathrm{C}$ bonds, showing a delocalized $\pi$-electron system within the N3-C3-C1-C3\#1-N3\#1 unit. The C-N bond lengths within these two amidinate groups differ due to different coordination numbers of the $\mathrm{N}$ atoms, whereas the $\mathrm{C}-\mathrm{N}$ bond lengths within the N1-C2-N1\#1 unit indicate delocalized $\pi$ electrons.

To summarize, the methanetrisamidines $\left\{\mathrm{HC}[\mathrm{C}(\mathrm{NR}) \mathrm{NHR}]_{3}(\mathrm{R}=\right.$ $i$-Pr 2a, $\mathrm{Ph} \quad 2 \mathbf{c})$ and ene-1,1-diamidine-2,2-diamine $\left.\left\{\mathrm{C}[\mathrm{C}(\mathrm{NPh}) \mathrm{NHPh})_{2}\right]_{2}\left[\mathrm{C}(\mathrm{NHPh})_{2}\right]\right\} \mathbf{2} \mathbf{b}$ were formed by an unforeseen carbodiimide elimination reaction upon hydrolysis of the corresponding tetranuclear zinc complexes. The crystal structures of the $\mathrm{N}-\mathrm{H}$ and $\mathrm{C}-\mathrm{H}$ tautomers $\mathbf{2 b}$ and $\mathbf{2 c}$ exhibit structural evidence of N,C tautomerism in amidines for the first time. In solution, the equilibrium between $\mathbf{2 b}$ and $\mathbf{2 c}$ depends to some extent on the polarity of the solvent. Quantum chemical calculations revealed the $\mathrm{N}-\mathrm{H}$ tautomers to be energetically favored compared to the $\mathrm{C}-\mathrm{H}$ tautomers for $\mathrm{Ph}$ - and $\mathrm{H}$-substituted trisamidines, whereas the $\mathrm{C}-\mathrm{H}$ tautomer of the $i$-Pr substituted complex is slightly lower in energy than the N-H tautomer. Reactivity studies showed that these novel ligands can be either protonated at the Lewis-basic $\mathrm{N}$ centers or metalated by organometallic complexes at the $\mathrm{N}-\mathrm{H}$ moieties.

\section{Experimental Section}

Full details are given in the electronic supplement.

Received: ((will be filled in by the editorial staff))

Published online on ((will be filled in by the editorial staff))

Keywords: Tautomerism $\cdot$ X-ray diffraction - ab-initio calculations . Imine $\cdot$ Enamine

[1] a) J. Barker, M. Kilner, Coord. Chem. Rev. 1994, 133, 219; b) F. T. Edelmann, Adv.Organomet. Chem. 2008, 57, 1535; c) M. P. Coles, Dalton. Trans. 2006, 118, 985.

[2] a) K. A. Schug, W. Lindner, Chem. Rev. 2005, 105, 67; b) M. W. Hosseini, Coord. Chem. Rev. 2003, 240, 157.

[3] a) C. Nastruzzi, R. Gambari, Cancer Lett. 1990, 50, 93-102; b) R. R. Tidwell, L. L. Fox, J. D. Geratz, Biochim. Biophys. Acta 1976, 445, 729-738.

[4] a) J.-A. Gautier, M. Miocque, C. C. Farnoux, in The Chemistry of Amidines and Imidates, Vol. 1 (Eds: S. Patai), JOHN WILEY \& SONS, London, 1975, pp. 283-348. b) R. L. Shriner, F. W. Neumann, Chem. Rev, 1944, 35(3), 351.

[5] a) A. Kraft, R. Fröhlich, Chem. Commun. 1998, 1085; b) A. Kraft, Perkin Trans. 1999, 1, 705; c) S. K. Mandal, L. K. Thompson, M. J. Newland, E. J. Gabe, F. L. Lee, Chem. Commun. 1989, 744; d) S. S. Tandon, L. K. Thompson, J. N. Bridson, J. C. Dewan, Inorg. Chem. 1994, 33, 54; e) A. W. Cordes, R. C. Haddon, R. G. Hicks, R. T. Oakley, T. T. M. Palstra, L. F. Schneemeyer, J. V. Waszczak, J. Am. Chem. Soc. 1992, 114, 5000; f) R. T. Boeré, R. T. Oakley, R. W. Reed, J. Organomet. Chem. 1987, 331, 161; g) J. Grundy, M. P. Coles, P. B. 
Hitchcock, J. Organomet. Chem. 2002, 662, 178; h) J. R. Hagadorn, J. Arnold, Angew. Chem. 1998, 110, 1813; Angew. Chem. Int. Ed. 1998, 37, 1729; i) H. Kawaguchi, T. Matsuo, Chem. Commun. 2002, 958; j) J. F. Li, L. H. Weng, X. H. Wei, D. S. Liu, Dalton Trans. 2002, 1401; k) C. T. Chen, L. H. Rees, A. R. Cowley, M. L. H. Green, Dalton Trans. 2001, 1761; 1) H. A. Jenkins, D. Abeysekera, D. A. Dickie, J. A. C. Clyburne, Dalton Trans. 2002, 3919; m) S.-D. Bai, J.-P. Guo, D.-S. Liu, W.-Y. Wong, Eur. J. Inorg. Chem. 2006, 4903; n) J. R. Babcock, C. Incarvito, A. L. Rheingold, J. C. Fettinger, L. R. Sita, Organometallics 1999, 18, 5729.

[6] a) F. D. Chattaway, J. Chem. Soc., Trans., 1910, 97, 2099-2102; b) R. Scholl, W. Egerer, Liebigs Ann. Chem. 1913, 397, 301.

[7] a) M. Münch, U. Flörke, M. Bolte, S. Schulz, D. Gudat, Angew. Chem. 2008, 120, 1535; Angew. Chem. Int Ed. 2008, 47, 1512; b) S. Schmidt, S. Gondzik, S. Schulz, D. Bläser, R. Boese, Organometallics 2009, 28, 4371; c) S. Schmidt, B. Gutschank, S. Schulz, D. Bläser, R. Boese, C. Wölper, Eur. J. Inorg. Chem. 2011, 28, 4464.

[8] a) B. Gutschank, S. Schulz, U. Westphal, D. Bläser, R. Boese, Organometallics 2010, 29, 2093; b) B. Gutschank, S. Schulz, D. Bläser, R. Boese, C. Wölper, Organometallics 2010, 29, 6133.

[9] a) M. Göbel, T. M. Klapötke, P. Mayer, Z. Anorg. Allg. Chem. 2006, 632, 1043; b) R. Scholl, W. Egerer, Liebigs Ann. Chem. 1913, 397, 301.

[10] a) T. Whitehorne, J. P. Coyle, A. Mahmood, W. H. Monillas, G. Yap, S. Barry, Eur. J. Inorg. Chem. 2011, 3240. b) A. L. Brazeau, Z. Wang, C. N. Rowley, S. T. Barry, Inorg. Chem. 2006, 45, 2276.

[11] a) C. Berndt, T. Kaempchen, Chem. Ber. 1986, 119, 1101. b) J. Oszczapowicz, E. Raczynska, J. Osek, J. Magn. Reson. Chem. 1986, 24, 9. c) E. Raczynska, Perkin Trans. II 1986, 1189. c) E. Raczynska, R. Gawinecki, Trends Org. Chem. 1998, 7, 85.

[12] a) M. Pfau, M. Chiriacescu, G. Revial, Tetrahedron Lett. 1993, 34, 327. b) K. Sung, S.-H. Wu, R.-R. Wu, S.-Y. Sun, Org. Chem. 2002, 67, 4298. c) K. Ito, Y. Kizuka, Y. Hirano, J. Heterocycl. Chem. 2005, 42, 583.

[13] J. Goerdeler, R. Sappelt, Chem. Ber. 1967, 100, 2064.

[14] H. P. Figeys, A. Mathy, A. Dralants, Synth. Commun. 1981, 11(8), 655 .

[15] a) J. Brandenburg, C. Käpplinger, R. Beckert, Synthesis 1996, 1302; b) D. Müller, R. Beckert, J. Weston, W. Günther, H. Görls, M. Friedrich, Eur. J. Org. Chem. 2001, 4551.

[16] Bruker AXS D8 Kappa diffractometer with APEX2 detector (MoKa radiation, $\lambda=0.71073 \AA ; \mathrm{T}=100(1) \mathrm{K})$. The structures were solved by Direct Methods (SHELXS-97, G. M. Sheldrick, Acta Crystallogr Sect. A 1990, 46, 467) and refined by full-matrix least-squares on $\mathrm{F}^{2}$. Absorption corrections were performed semi-empirically from equivalent reflections on basis of multi-scans (Bruker AXS APEX2). All non-hydrogen atoms were refined anisotropically, methyl hydrogen atoms as rigid groups and others by a riding model. $\mathrm{NH}$ and $\mathrm{OH}$ hydrogen atoms were taken from the difference fourier synthesis and constrained. (SHELXL-97, Program for Crystal Structure Refinement, G. M. Sheldrick, Universität Göttingen, 1997 and shelXle, A Qt GUI for SHELXL. See also: Sheldrick, G. M. Acta Crystallogr. Sect. A 2008, 64, 112; C. B. Hübschle, G. M. Sheldrick, B. Dittrich, J. Appl. Cryst. 2011, 44, 1281-1284) 2b: $\left[\mathrm{C}_{40} \mathrm{H}_{34} \mathrm{~N}_{6}\right], \mathrm{M}=598.73$, colorless crystal $(0.42 \times 0.32 \times 0.26 \mathrm{~mm})$; monoclinic, space group $C c ; a=18.1738(16) \AA, b=10.3046(9) \AA, c=18.983(2) \AA ; \alpha=90^{\circ} \beta$ $=113.163(3)^{\circ} \gamma=90^{\circ}, V=3268.4(6) \AA^{3} ; Z=4 ; \mu=0.073 \mathrm{~mm}^{-1} ; \rho_{\text {ber. }}$. $=1.217 \mathrm{~g} \mathrm{~cm}^{-3} ; 37607$ reflexes $\left(2 \theta_{\max }=59^{\circ}\right), 8129$ unique $\left(R_{\text {int }}=\right.$ $0.0333) ; 415$ parameters, Flack-parameter $x=-0.7(15)$; largest $\mathrm{max} . / \mathrm{min}$. in the final difference Fourier synthesis $0.249 \mathrm{e} \AA^{-3} /-0.245$ $\mathrm{e} \AA^{-3}$; max./min. transmission $0.75 / 0.68 ; R_{1}=0.0435(\mathrm{I}>2 \sigma(\mathrm{I})), w R_{2}$ (all data $)=0.1076$. Due to the high standard deviation of $x$ the absolute structure could not be determined reliably. $2 \mathbf{c}$ : $\left[\mathrm{C}_{40} \mathrm{H}_{34} \mathrm{~N}_{6}\right.$ * $\left.\mathrm{C}_{2} \mathrm{H}_{3} \mathrm{~N}\right], \mathrm{M}=639.79$, colorless crystal $(0.24 \times 0.18 \times 0.13 \mathrm{~mm})$; triclinic, space group $P-1 ; a=12.3438(7), b=13.3509(7), c=$ $13.4235(8) \AA ; \alpha=60.586(2)^{\circ}, \beta=67.453(3)^{\circ} \gamma=66.088(3)^{\circ}, V=$ 1713.77(17) $\AA^{3} ; Z=2 ; \mu=0.075 \mathrm{~mm}^{-1} ; \rho_{\text {ber. }}=1.240 \mathrm{~g} \mathrm{~cm}^{-3} ; 28355$ reflexes $\left(2 \theta_{\max }=61^{\circ}\right), 10184$ unique $\left(R_{\text {int }}=0.0234\right) ; 442$ parameters; largest max./min. in the final difference Fourier synthesis $0.394 \mathrm{e}^{-3} /-$ $0.222 \mathrm{e}^{-3} ;$ max./min. transmission $0.75 / 0.67 ; R_{1}=0.0460(\mathrm{I}>2 \sigma(\mathrm{I}))$, $w R_{2}$ (all data) $=0.1192 .3:\left[\mathrm{C}_{40} \mathrm{H}_{36} \mathrm{~N}_{6}, 2\left(\mathrm{C}_{2} \mathrm{H}_{3} \mathrm{O}_{2}\right), 2\left(\mathrm{H}_{2} \mathrm{O}\right)\right], \mathrm{M}=$ 754.87, pale yellow crystal $(0.18 \times 0.15 \times 0.12 \mathrm{~mm})$; triclinic, space group $P-1 ; a=10.5079(11) \AA, b=13.5325(15) \AA, c=16.2636(19) \AA ;$ $\alpha=110.849(5)^{\circ}, \beta=92.152(5)^{\circ}, \gamma=111.876(5)^{\circ}, V=1966.6(4) \AA^{3} ; Z$ $=2 ; \mu=0.086 \mathrm{~mm}^{-1} ; \rho_{\text {ber. }}=1.275 \mathrm{~g} \mathrm{~cm}^{-3} ; 33622$ reflexes $\left(2 \theta_{\max }=50^{\circ}\right)$, 6990 unique $\left(R_{\text {int }}=0.0405\right) ; 505$ parameters; largest max. $/ \mathrm{min}$. in the final difference Fourier synthesis $0.229 \mathrm{e}^{-3} /-0.263 \mathrm{e}^{-3} ;$ max./min. transmission $0.75 / 0.69 ; R_{1}=0.0355(\mathrm{I}>2 \sigma(\mathrm{I})), w R_{2}($ all data $)=$ 0.0883 . The hydrogen atoms of $\mathrm{C} 72$ and $\mathrm{C} 82$ were refined as idealized disordered methyl group over two positions. $4 \mathbf{c}$ : $\left[\mathrm{C}_{48} \mathrm{H}_{54} \mathrm{Al}_{4} \mathrm{~N}_{6}\right], \mathrm{M}=$ 822.89 , yellow crystal $(0.25 \times 0.10 \times 0.08 \mathrm{~mm})$; monoclinic, space group $C 2 / c ; a=17.4755(9) \AA, b=15.5339(8) \AA, c=18.5007(11) \AA$; $\alpha=\gamma=90^{\circ}, \beta=116.831(2)^{\circ}, V=4481.6(4) \AA^{3} ; Z=4 ; \mu=1.145 \mathrm{~mm}^{-}$ ${ }^{1} ; \rho_{\text {ber. }}=1.220 \mathrm{~g} \mathrm{~cm}^{-3} ; 23163$ reflexes $\left(2 \theta_{\max }=61^{\circ}\right), 6861$ unique $\left(R_{\text {int }}\right.$ $=0.0334) ; 263$ parameters; largest max. $/ \mathrm{min}$. in the final difference Fourier synthesis $0.499 \mathrm{e}^{-3} /-0.235 \mathrm{e}^{-3}$; max./min. transmission $0.75 / 0.66 ; R_{1}=0.0398(\mathrm{I}>2 \sigma(\mathrm{I})), w R_{2}$ (all data) $=0.1087$. The crystallographic data (without structure factors) were deposited as "supplementary publication no. CCDC-868839 (2b), CCDC-868842 (2c), CCDC-868841 (3) and CCDC-868840 (4c)" at the Cambridge Crystallographic Data Centre. These data can be obtained free of charge from The Cambridge Crystallographic Data Centre: CCDC, 12 Union Road, Cambridge, CB21EZ (Fax: (+44)1223/336033; E-mail: deposit@ccdc.cam-ak.uk).

[17] Detailed informations are given in the electronic supplement.

[18] Starting from the crystal structures the molecule geometries of $\mathbf{2} \mathbf{b}$ and 2c were optimized with tightened convergence thresholds and an improved DFT integration grid at the DFT level including a thirdgeneration dispersion energy correction (DFT+D3; S. Grimme, J. Antony, S. Ehrlich, H. Krieg, J. Chem. Phys. 2010, 132, 154104/118.). The BLYP exchange correlation functional (a) P. A. M. Dirac, Proc. Roy. Soc. A 1929, 123, 714; b) J. C. Slater, Phys. Rev. 1951, 81, 385; c) A. D. Becke, Phys. Rev. A 1988, 38, 3098. d) C. Lee, W. Yang, R. G. Parr, Phys. Rev. B 1988, 37, 785.) and a basis set of triple zeta valence quality (def2-TZVP; F. Weigend, R. Ahlrichs, Phys. Chem. Chem. Phys. 2005, 7, 3297.) were used along with the corresponding auxiliary basis set (F. Weigend, Phys. Chem. Chem. Phys. 2006, 8 , 1057.) in the resolution-of-the-identity (RI) approximation as implemented in Turbomole V6.3 (TURBOMOLE V6.3 2009, University of Karlsruhe and Forschungszentrum Karlsruhe $\mathrm{GmbH}$, 1989-2007, TURBOMOLE GmbH, since 2007; available from http://www.turbomole.com; a) R. Ahlrichs, M. Bär, M. Häser, H. Horn, C. Kölmel, Chem. Phys. Lett. 1989, 162, 165; b) O. Treutler, R. Ahlrichs, J. Chem. Phys. 1995, 102, 346; c) M. von Arnim, R. Ahlrichs, J. Chem. Phys. 1999, 111,9183.).

[19] Valence-only MP2 calculations were performed in the RI approximation with a larger orbital basis set (def2-TZVPP) and the corresponding auxiliary basis set (F. Weigend, M. Häser, H. Patzelt, R. Ahlrichs, Chem. Phys. Letters 1998, 294, 143).

[20] P. Deglmann, K. May, F. Furche, R. Ahlrichs, Chem. Phys. Lett. 2004, 384,103 . 


\section{Methanetrisamidines}

Benjamin Gutschank, Stephan Schulz, Michael Marcinkowski, Georg Jansen,

Heinz Bandmann, Dieter Bläser,

Christoph Wölper

Page

Synthesis, Structure, Tautomerism and Reactivity of Methantrisamidines

Page -

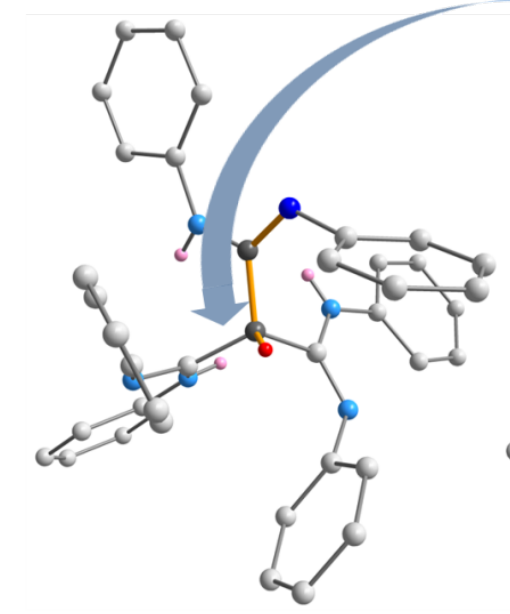

$\mathrm{CH}$ - NH Tautomerism

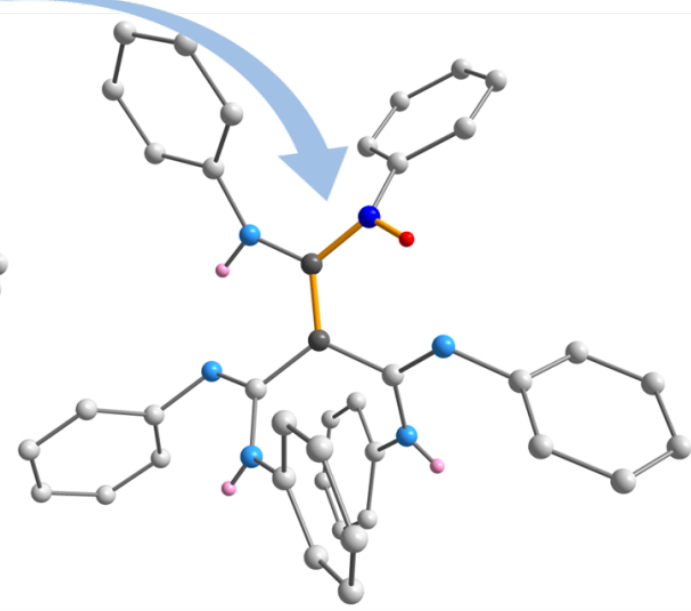

Two tautomeric forms of a methanetrisamidine were structurally characterized for the first time and their reactivity as proton acceptors and multianionic ligand was demonstrated. 
DuEPublico

Duisburg-Essen Publications online

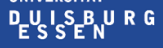

offen im Denken

$\mathbf{U b} \mid \begin{aligned} & \text { universitäts } \\ & \text { bibliothek }\end{aligned}$

This text is made available via DuEPublico, the institutional repository of the University of Duisburg-Essen. This version may eventually differ from another version distributed by a commercial publisher.

DOI: $\quad 10.1002 /$ anie.201205030

URN: urn:nbn:de:hbz:464-20201112-104551-7

This is the peer reviewed version of the following article: Angew. Chem. Internat. Ed. 2012, 51, 10893-10897, which has been published in final form at:

https://doi.org/10.1002/anie.201205030

All rights reserved. 